\title{
Hajj health istithaah amid the COVID-19 pandemic
}

\author{
Muchtaruddin Mansyur
}

Check for updates

The Hajj, which refers to the annual Islamic pilgrimage to Makkah, is a mandatory religious duty for Muslims as long as they are physically and financially capable and can continue to support their family during their absence. Another pilgrimage-related mass gathering event is Umrah. Muslims perform the Hajj during a specific season in the $12^{\text {th }}$ month of the Hijrah calendar, that is, from the $9^{\text {th }}$ until the $12^{\text {th }}$ of Dhu alHijjah. By contrast, the Umrah can be performed at any time of the year. The Umrah is also considered a minor pilgrimage because it is similar to the Hajj in the sense that the necessary events take place in holy cities, such as Makkah or Mecca and Madinah, but do not include the rituals performed in Arafah and Mina. Although the Umrah is not compulsory, it is highly recommended and considered an alternative before Hajj, which has a prolonged waiting period.

\section{Hajj and mass gathering medicine}

The Hajj and Umrah are excellent opportunities for implementing mass gathering medicine because these events are the most significant recurring single mass gatherings in the world. During these events, over 2 million pilgrims assemble in confined areas for several days. These pilgrims usually present a wide range of ages, health statuses, susceptibility to illness, and hygiene sophistication and come in close contact with each other, thereby creating an enormous public health challenge. Several mass gathering-related health risks, including accidents, infectious diseases, aggravated non-communicable diseases (NCDs), and heatstroke, may occur during these events. In 2002, Arabi and Alhamid ${ }^{1}$ identified the top five diseases causing mortality to pilgrims, including cardiovascular diseases (with hypertension), respiratory illnesses causing respiratory and cardiac system failure, traffic accidents and other traumas, cerebrovascular diseases, and senility; today, these findings remain valid. The causes of mortality among Indonesian pilgrims in 2016 are similar, except that traffic accidents and other traumas in this group are minimal. ${ }^{2}$ Alzahrani et $a^{3}$ reported that the top five diseases during the Hajj and Umrah include respiratory diseases, musculoskeletal disorders, skin diseases, gastrointestinal disorders, and eye and ear diseases. Preexisting health conditions, such as cardiovascular disorders, metabolic disorders, and other chronic diseases, as well as the physical demands of undertaking the requisite rituals, highlight the importance of health preparedness for the Hajj. However, the health risks described above are ignored by many Muslims because they believe that death at holy cities while performing the Hajj is a blessed occurrence and rewarded in heaven. Thus, pilgrims disregard the significance of health fitness for the Hajj and would not place the Hajj health preparedness as a priority pre-departure activities if health personnel informed them that Hajj health istithaah objective is reducing the morbidity and mortality rate. The efforts to promote health preparations to prevent and control infectious diseases and management of NCDs and other health risks should employ the phrase "Hajj ritual completeness" instead of the terms "morbidity" and "fatality" to stress the value of these concepts.

In 2016, the government of the Republic of Indonesia published Decree No. 15 by the Ministry of Health concerning Hajj health istithaah. ${ }^{4}$ Istithaah in Arabic literally means capable and supports the idea of health fitness for the Hajj. This decree defined the health requirements of Indonesian Hajj pilgrims, including, among others, absence of tuberculosis, no severe chronic diseases, and completion of mandatory vaccination. The decree also regulated approaches to prevent and control health risks and vulnerabilities through comprehensive and continuous health monitoring in community health centers (puskesmas) at least 2 years prior to a pilgrim's departure schedule. 
The main idea behind Hajj health istithaah is not the restriction or limitation of pilgrims performing the Hajj; instead, Hajj health istithaah seeks to improve pilgrims' physical capacity to ensure that they complete all mandatory sequences of the Hajj.

\section{Coronavirus disease 2019 (COVID-19) pandemic and postponement of the Hajj 2020}

Reports of a virus causing COVID-19 were widely circulated in December 2019. The virus is transmitted between humans and has spread throughout the world following human activities, especially crosscountry and -continental travel. On March 11, 2020, the World Health Organization Director-General declared the viral infection a pandemic; by this time, the number of infected had reached 118,000 cases in more than 114 countries and resulted in the deaths of over 4,000 people. As of May 28, 2020, COVID-19 has affected more than 200 countries; moreover, 5,593,631 cases, including 353,334 deaths, have been confirmed. 5 The Kingdom of Saudi Arabia has also been affected by the COVID-19 pandemic and applied a lockdown policy, including the holy cities Makkah and Madinah, to protect its people from further infection. This policy has some important implications for visitors of the country, such as suspension of the Umrah pilgrimage, closure of the Grand Mosque for a specific length of time, temporary closure of the Kaaba, and suspension of shipping services and all international flights. Because the spread of infection has not been controlled and the pilgrimage season is expected to begin within the next 2 months, Saudi Arabia has, in fact, considered cancelling all Hajj rituals.

Indonesia contributes a large proportion of Hajj pilgrims; for example, 209,120 Indonesian pilgrims were recorded in 2010 and 220,000 pilgrims were recorded in 2017 . The country has contributed $25 \%$ of all Hajj pilgrims, or approximately 52,500 people, over the last 60 years, including nearly 5,000 individuals aged over 75 years. The ratio of pilgrims aged over 40 years old relative to the total number of pilgrims is $85.7 \%$ or approximately 180,000 people. ${ }^{6}$ This age group is at high risk of COVID-19 infection.

While Saudi Arabia may choose to continue holding the Hajj this year, very few countries have been declared free of COVID-19; and Indonesia decide to postpone it. Therefore, countries sending their citizens for pilgrimage are encouraged to maximize the remaining time prior to the next season 1442 or Hajj 2021 by building better pilgrim health fitness status through health preparation programs. These preparation programs should consider different phases of the pilgrimage, including before departure, during the Hajj, and after one's travel. ${ }^{7}$ The pre-departure program may include regular physical examinations, mandatory and recommended immunization, supervised physical exercise, balanced nutrition, and hygienic behavior education. Standard procedures and adequate quarantine facilities should be established to prevent the spread of severe acute respiratory syndrome coronavirus 2 and other causes of potential communicable disease outbreaks. Psychological support for pilgrims with increased mental distress due to prolonged social distancing and postponement of their Hajj schedule should also be provided. During the Hajj, pilgrims should have adequate facilities for handwashing, face masks, clean water, nutritious and safe food, and suitable accommodations. Pilgrimsending countries should consider encouraging their pilgrims with chronic and underlying conditions and those aged over 65 years to postpone their travel voluntarily until the COVID-19 pandemic is fully controlled. ${ }^{8}$ Upon the pilgrims' return, sender countries should ensure that medical emergency services and health surveillance are in place and that returnees are provided with health alert cards.

A critical point for prospective Indonesian pilgrims is their awareness of the health istithaah required by the Hajj. Although a recent study showed that Indonesian pilgrims generally have good health attitudes and disease prevention practices to avoid, for example, heat-related illness, ${ }^{9}$ further improvements to establish and maintain a healthy and hygienic lifestyle are necessary. The goal of health fitness for all Hajj pilgrims and, in turn, successful completion of all Hajj activities by these pilgrims can be achieved by consistently implementing health istithaah by all Hajj program stakeholders during the waiting period.

From Indonesian Medical Hajj Association (PERDOKHI); Department of Community Medicine, Faculty of Medicine, Universitas Indonesia, Jakarta, Indonesia; Southeast Asian Ministers of Education Organization-Regional Center for Food and Nutrition (SEAMEO-RECFON), Jakarta, Indonesia pISSN: 0853-1773 • elSSN: 2252-8083 https://doi.org/10.13181/mji.com.204764

Med J Indones. 2020;29:115-7

Corresponding author:

Muchtaruddin Mansyur

E-mail: muchtaruddin.mansyur@ui.ac.id 


\section{REFERENCES}

1. Arabi YM, Alhamid SM. Emergency room to the intensive care unit in Hajj. The chain of life. Saudi Med J. 2006;27(7):937-41.

2. Mansyur M. Indonesian Hajj health preparedness. Presented at: WHO Intercountry Consultation on Mass Gatherings Preparedness and Management; 2017 Feb 21-22; Jakarta.

3. Alzahrani AG, Choudhry AJ, Al Mazroa MA, Turkistani AH, Nouman GS, Memish ZA. Pattern of diseases among visitors to Mina health centers during the Hajj season, 1429 H (2008 G). J Infect Public Health. 2012;5(1):22-34.

4. Ministry of Health of the Republic of Indonesia. The Ministry Decree No 15 Year 2016 concerning Hajj health istithaah [Internet]. 2016 [cited 2020 May 28]. Jakarta: Ministry of Health of the Republic of Indonesia. Available from: http://hukor. kemkes.go.id/uploads/produk_hukum/PMK_No. 15_ttg_ Istithaah_Kesehatan_Jamaah_Haji_.pdf. Indonesian.
5. World Health Organization. Coronavirus disease (COVID-19) outbreak situation [Internet]. 2020 [cited 2020 May 28]. Available from: https://www.who.int/emergencies/diseases/ novel-coronavirus-2019?gclid=EAlalQobChMIveu8ouHC6QIVoZ 7CCh3bCQ1cEAAYASAAEgLB7PD BwE.

6. Indonesian Hajj Health Center, Ministry of Health of the Republic of Indonesia. 2016 Hajj health center performance report. Jakarta: Ministry of Health of the Republic of Indonesia; 2016. Indonesian.

7. Ahmed QA, Arabi YM, Memish ZA. Health risks at the Hajj. Lancet. 2006;367(9515):1008-15.

8. Ebrahim SH, Memish ZA. COVID-19: preparing for superspreader potential among Umrah pilgrims to Saudi Arabia. Lancet. 2020;395(10227):e48.

9. Yezli S, Mushi A, Yassin Y, Maashi F, Khan A. Knowledge, attitude and practice of pilgrims regarding heat-related illnesses during the 2017 Hajj mass gathering. Int J Environ Res Public Health. 2019;16(17):3215.

\section{Hajj health management in Indonesia}

Eka Jusup Singka, Innes Ericca

The Hajj, one of the five pillars of Islam, is a "once in a lifetime" mandatory worship for all Muslims. However, only those who meet certain conditions, collectively called "conditions of obligation," are obliged to perform the Hajj. These conditions are Islam religion, baligh or maturity, freedom, and istithaah or capability.
Check for updates

Istithaah is defined as the physical, mental, financial, and safe ability of a person to perform the pilgrimage without neglecting their familial responsibilities. Physical and mental istithaah, also known as health istithaah, is defined as the ability of pilgrims to perform Hajj rituals following Islamic guidance from the aspect of health.
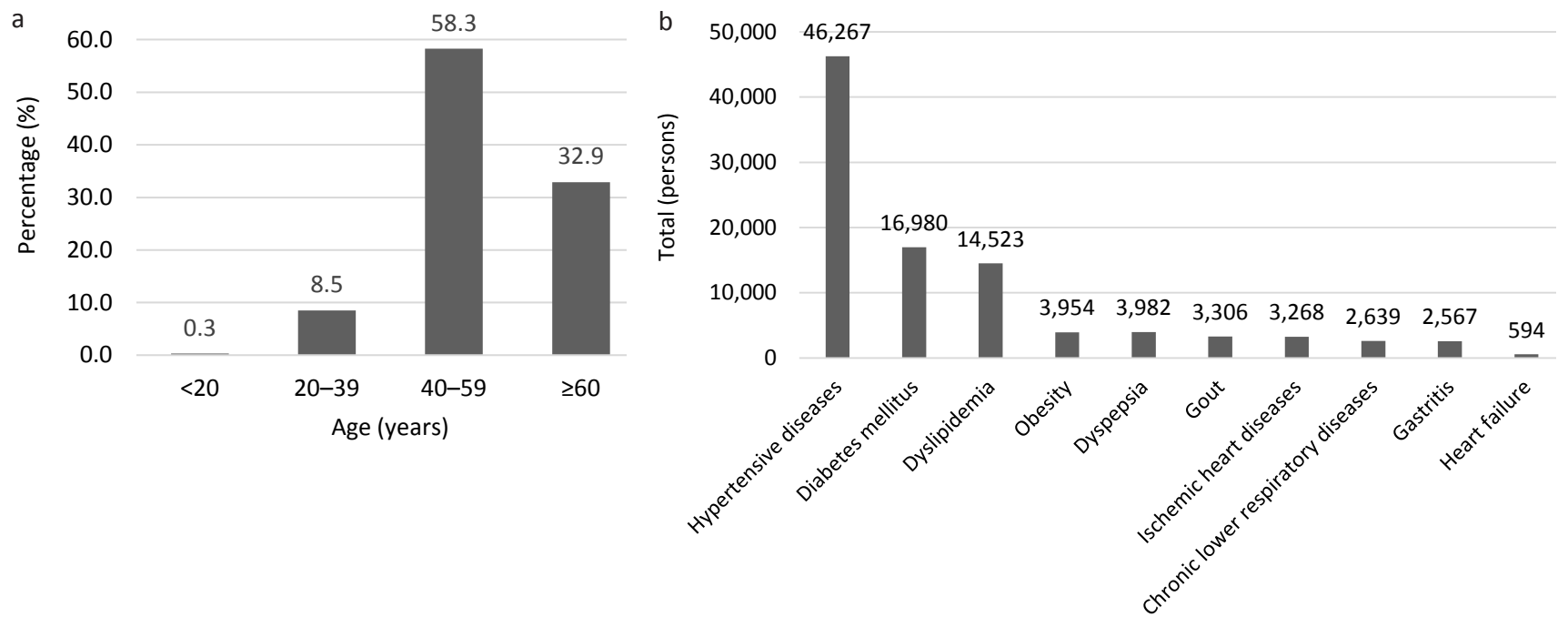

Figure 1. Estimated total number of Indonesian pilgrims for 2020. (a) Total number of Indonesian pilgrims according to age group; (b) ten most common preexisting diseases/condition of Hajj pilgrims

Copyright @ 2020 Authors. This is an open access article distributed under the terms of the Creative Commons Attribution-NonCommercial 4.0 International License (http:// creativecommons.org/licenses/by-nc/4.0/), which permits unrestricted non-commercial use, distribution, and reproduction in any medium, provided the original author and source are properly cited. For commercial use of this work, please see our terms at https://mji.ui.ac.id/journal/index.php/mji/copyright. 